\title{
Development and Validation of an Attitude Scale towards Online Teaching and Learning for Higher Education Teachers
}

\author{
Anupma Sangwan ${ }^{1} \cdot$ Anurag Sangwan ${ }^{2} \cdot$ Poonam Punia $^{3}$ (I)
}

Accepted: 5 November 2020 / Published online: 12 November 2020

(C) Association for Educational Communications \& Technology 2020

\begin{abstract}
The aim of this study is to develop an attitude scale towards online teaching and learning for higher education teachers. It included 687 participants (77 Professors, 67 Associate Professors and 543 Assistant Professors) from various colleges and Universities of India. This tool development was a part of research conducted to examine the preparedness of Indian higher education teachers during the period of lockdown due to Covid-19 pandemic. After reviewing related literature, initially 37 items related with the attitude of teachers towards online education were framed. Later on, 11 items were modified and four were deleted as per the opinions of the experts. The draft scale consisting of 33 items was administered on teachers and data was collected with the help of Google forms. Item analysis was carried out using t-value and r-value. Reliability of scale was determined by using Cronbach Alpha value (0.88) and split-halt correlation (0.82). After item analysis, the scale items were reduced to 30 and four factors were established as a result of factor analysis (Principal Component Analysis). Psychometric scale analyses have shown that this scale is valid, reliable and thus can be used in the evaluation of teachers 'attitudes towards online teaching and learning.
\end{abstract}

Keywords Attitude $\cdot$ Online education $\cdot$ Teaching and learning $\cdot$ Higher education

\section{Introduction}

Education itself means growing in the light of knowledge and living life in a purposeful manner. It is a continuous process which starts with the birth of an individual and plays essential role in everyone's life. There are several ways of attaining education; however, one thing that has influenced the education delivery mechanism to a large extent is use of technology. Many research studies have highlighted the importance of technology in different walks of life (Lea et al. 2001; Jovanova-Mitkovska 2010; Lazar 2015 and Ghavifekr and Rosdy 2015). Technology has played instrumental role in making teaching more efficient and effective (Girgurovic 2010; Wells et al. 2008).

Poonam Punia

poonampunia13@gmail.com

1 Department of Computer Science and Engineering, GJUS \& T, Hisar, India

2 UGC Human Resource Development Center, GJUS \& T, Hisar, India

3 Institute of Teacher Training and Research, BPS Women University, Khanpur Kalan, Haryana Sonepat, India
The use of technology in education can be traced back in twentieth century after the introduction of personal computers in 1980s. In the past two decades, computer technology has progressed in a quite staggering way and the wave of digitalization gained heights with the advent of internet. It is now used in business, online bank transactions, maintaining social connections with people and e-learning (Kraut et al. 1999). This digital revolution has brought radical changes in the field of education all over the world. Moreover, today's generation is digital native and technology is completely woven in different areas of their life. In the recent years, we have witnessed the increasing use of internet in daily life by everyone including teachers (Anderson and Tracey 2001; Haythornthwaite and Wellman 2002). In fact, in this digital climate, teacher can take its benefits by increasing his or her digital competency (Kalanda 2005). Online education in the last decade has gained popularity and wide recognition as a mode of carrying out higher education (UNESCO 2009).

Online education is known with many names like elearning, online learning, mobile learning ( $\mathrm{m}$ - learning), internet learning and many others. However, in simple language, is an electronically supported way of learning wherein, teacher and students interact via internet. It is usually done outside conventional classroom and students 
access the educational curriculum, complete and submit assignments, and give test through online mode only. Some researchers believe that it can be used as best substitute of classroom teaching, as it deals with the constraints of accessing education (Weller 2007; Garrison 2011). Many teachers believe that traditional methods are not sufficient for the students in today's era (Enayati et al. 2012). Technology integration can help in better learning of students (Draude and Brace 1999; Lea et al. 2001; Salmon 2011 and Costley 2014). Hence, the use of technology by the teacher cannot be ignored and digital literacy has become one of the prerequisite of the teacher's competency.

The success of any online education depends upon the attitude of teachers towards online learning to a large extent (Van Den Berg et al. 2006; Van Raaij and Schepers 2008; Wasserman and Migdal 2019). Attitude is a hypothetical construct invented by psychologists for explaining any phenomenon of interest. It is the discernment about anything based on the cognitive, affective and behavioural experience (Schwarz 2007). It is a very important aspect of one's personality which influences the action of a person. There are various factors which may influence the attitude of a teacher towards online education like knowledge, desire to learn (Papp 1998), perceived ease of doing (Nair and Das 2012), beliefs and external environment. The customs and value pattern, and social environment also influence the attitude of person (Gardner et al. 1993). It has been observed that teacher with positive attitude are more familiar with web based technologies (Uzunboylu 2007). Gender differences may also account for differences in the attitude of teachers. Lateef and Alaba (2013) determined gender as a factor in use of online education and female teachers had shown more favourable responses for online education. However, in contrary, many research studies have found that gender does not influence online behaviour (Graff 2003; Meelissen and Drent 2008; Adebowale et al. 2010). Even, student's attitude towards technology may be influenced by method of teaching used by their teacher (Kalanda 2005). Younger teachers with less teaching experience have shown more positive attitude towards professional development activities (Hürsen 2012).

Various research studies have reported favourable attitude for e-learning in most of the teachers (Suri and Sharma 2017; Krishnakumar and Rajesh 2011; Akaslan and Law 2011). Even though, most of the recent studies have shown teachers' positive attitude towards technology, yet, it has been observed that the use of technology is more prevalent in research than teaching (Duart 2011). Many teachers face difficulties while teaching through online mode. Most common barriers faced by teachers are: lack of information and computer technology (ICT) skills, professional training, limited access and rigid curriculum (Buabeng-Andoh 2012). Insufficient training, lack of time, poor network connectivity, and lack of proper institutional policies for e-learning are some of the perceived barriers towards online education (Al Gamdi and Samarji 2016; Panda and Mishra 2007). Professional barriers are more prevalent in arts and humanities (Mercader and Gairín 2020). Despite, all these barriers, many teachers are changing their beliefs and adapting according to technological advancements (IvyPanda 2019, June 10). Most of the teachers have the belief that technology can be proved as a useful tool with adequate training (Wang et al. 2003). Hence, Teachers should be provided more opportunity of applying new technology periodically in order develop positive attitude towards technology (Mahajan 2016).

\section{Conceptual Framework}

After completing extensive review of literature and discussing with the experts of the field, it has been observed that attitude development is a continuous process which is influenced by knowledge about the subject, feeling and previous experience (Eagly and Chaiken 2007; Fazio 2007). Alanazy (2017) revealed that online learning attitude is significantly correlated with computer efficacy, technology attitude and computer anxiety. The factors which affect teacher's attitude towards technology have been categorised into internal and external factors (Teo 2009). Belief of teacher about technology has been considered as the internal factor which is determined by the degree to which a teacher perceive it favourable or not. External factors include technical factors like complexity (Weller 2007), facilitators, organizational support, infrastructure, training (Rogers 2003; Chien et al. 2014; Teo 2009), and earlier exposure to computer (Krishnakumar and Rajesh 2011). As per Technology Acceptance Model (TAM) given by Davis' (1986), there are four constructs which determines acceptance towards technology are: "external variables, perceived usefulness, perceived ease of use and attitude towards e-learning." Many tools for measuring the attitude towards technology like "The Computer Attitude Measure" (Kay 1993), "The Computer Attitudes Scale for Secondary Students" (Jones and Clarke 1994), and "Attitude Scale towards Using Instructional Technologies for Pre-Service Teachers"(Metin et al. 2012) are available. Teo (2010) constructed an "E- learning Acceptance Measure (EIAM)" based on three factors: tutor quality, perceived usefulness and facilitating conditions. Kisanga and Ireson (2016) developed and validated TeLRA scale for assessing e-learning attitude of the teachers which was 
Table 1 Demographic detail of the sample

\begin{tabular}{llll}
\hline & & Frequencies (f) & Percentage (\%) \\
\hline \multirow{2}{*}{ Gender } & Female & 298 & 43.4 \\
& Male & 389 & 56.6 \\
& Less than 30 Years & 127 & 18.5 \\
& 30-40 Years & 327 & 47.6 \\
& 40-50 Years & 181 & 26.3 \\
Mepartment & Arts/Humanities 50 Years & 52 & 7.6 \\
& Commerce/Economics/Management & 55 & 16.0 \\
& Education & 52 & 8.0 \\
& Engineering & 135 & 7.6 \\
& Law & 15 & 19.7 \\
& Others & 27 & 2.2 \\
& Pharmacy & 3 & 3.9 \\
& Science & 290 & 0.4 \\
& Less than 5 Years & 196 & 42.2 \\
& 5-10 Years & 198 & 28.5 \\
& 10-20 Years & 212 & 28.8 \\
Designation & More than 20 Years & 81 & 30.9 \\
& Assistant Professor & 543 & 11.8 \\
& Associate Professor & 67 & 79.0 \\
& Professor & 77 & 9.8 \\
& & & 11.2 \\
\hline
\end{tabular}

based on four factors. Martin et al. (2019) developed faculty readiness instrument considering faculty attitude towards importance of online and their ability to teach online confidently. However, after examining different available tools of assessing attitude towards technology, it has been observed that very few are reliable in context to Indian conditions. This is so because, many available tools have been developed for studying the attitude of teachers towards using technology in developed countries (who have been using online education in its full operational mode from last one decade), which may not be valid for developing countries, where online learning is still at its infant stage. In addition, the statements of such tool were not appropriate in cross-cultural conditions. Moreover, the researchers are specifically interested in understanding the attitude of teachers towards online teaching and learning. Therefore, this tool was developed and validated.

\section{Methodology}

In this study, for the development of scale, survey method was used. Data collection was done by using Google forms during the lockdown period in India due to Covid-19 crisis in the month of April 2020.

\section{Sample}

The sample of the study comprised of 687 teachers from 125 colleges, 7 National Institutes and 49 State and Central Universities of India. The demographic detail of the sample is given in Table 1 .

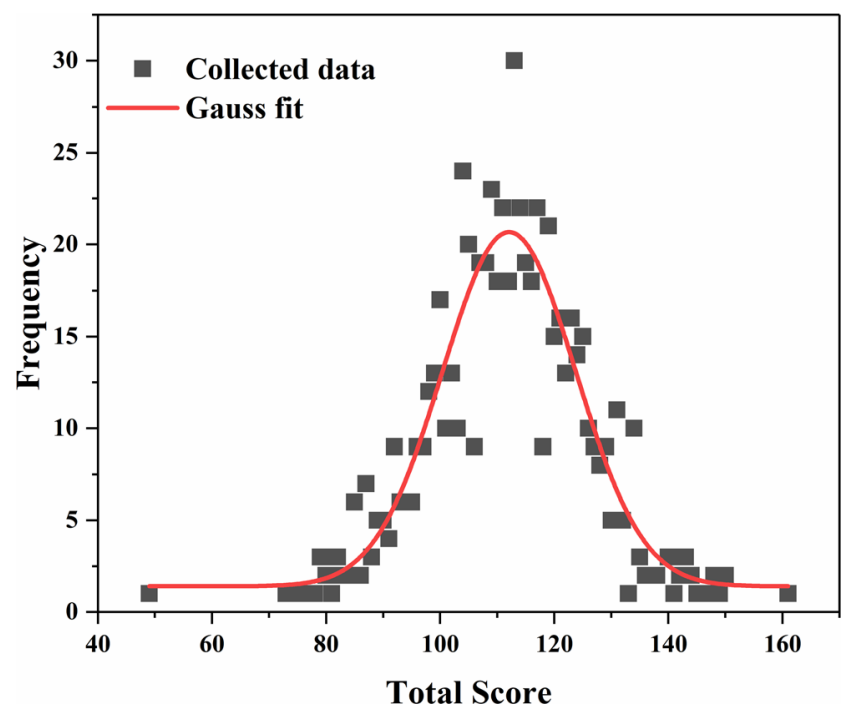

Fig. 1 Fitting of data collected from teachers for the development of "Attitude scale for teachers towards online teaching and learning" with Gaussian function 
Table 2 Mean, standard deviation, $p$ value, t-value and r-value for each item $(n=687)$

\begin{tabular}{|c|c|c|c|c|c|c|c|c|c|c|c|c|c|c|c|}
\hline \multirow[t]{2}{*}{ Item No. } & \multicolumn{2}{|c|}{ Upper } & \multicolumn{2}{|c|}{ Lower } & \multirow[b]{2}{*}{$\mathrm{T}$} & \multirow[b]{2}{*}{$\mathrm{p}$} & \multirow[b]{2}{*}{$\mathrm{R}$} & \multirow[t]{2}{*}{ Item No. } & \multicolumn{2}{|c|}{ Upper } & \multicolumn{2}{|c|}{ Lower } & \multirow[b]{2}{*}{$\mathrm{t}$} & \multirow[b]{2}{*}{$\mathrm{p}$} & \multirow[b]{2}{*}{$\mathrm{r}$} \\
\hline & M & S.D. & M & S.D. & & & & & M & S.D. & M & S.D. & & & \\
\hline 1 & 4.51 & .758 & 3.87 & .716 & 8.3 & .000 & .287 & 18 & 3.32 & .914 & 2.03 & .741 & 14.9 & .000 & .496 \\
\hline 2 & 4.35 & .684 & 3.54 & .792 & 10.5 & .000 & .361 & 19 & 3.60 & .845 & 2.22 & .882 & 15.4 & .000 & .485 \\
\hline 3 & 2.89 & 1.13 & 2.21 & .874 & 6.4 & .000 & .234 & 20 & 2.46 & .953 & 1.74 & .828 & 7.7 & .000 & .250 \\
\hline 4 & 3.98 & .795 & 2.66 & .928 & 14.7 & .000 & .484 & 21 & 4.42 & .603 & 3.58 & .829 & 11.2 & .000 & .466 \\
\hline 5 & 3.80 & .808 & 2.86 & .917 & 10.4 & .000 & .378 & 22 & 3.34 & .942 & 2.27 & .796 & 11.8 & .000 & .393 \\
\hline 6 & 4.44 & .649 & 2.96 & .974 & 17.2 & .000 & .583 & 23 & 4.18 & .596 & 3.26 & .947 & 11.1 & .000 & .412 \\
\hline 7 & 4.06 & .709 & 2.65 & .851 & 17.3 & .000 & .556 & 24 & 4.20 & .541 & 3.59 & .723 & 9.2 & .000 & .408 \\
\hline 8 & 4.54 & .509 & 3.47 & .820 & 15.1 & .000 & .567 & 25 & 4.58 & .493 & 3.86 & .790 & 10.5 & .000 & .437 \\
\hline 9 & 4.04 & .696 & 2.42 & .910 & 19.2 & .000 & .547 & 26 & 4.50 & .522 & 3.76 & .688 & 11.7 & .000 & .490 \\
\hline 10 & 4.09 & .663 & 2.88 & .865 & 15.05 & .000 & .494 & 27 & 3.88 & .823 & 4.00 & .788 & -1.47 & .140 & .387 \\
\hline 11 & 4.01 & .649 & 2.90 & .876 & 13.8 & .000 & .456 & 28 & 4.25 & .602 & 3.48 & .772 & 10.6 & .000 & .342 \\
\hline 12 & 3.33 & .996 & 2.00 & .771 & 14.4 & .000 & .512 & 29 & 3.99 & .866 & 3.14 & .983 & 8.8 & .000 & .381 \\
\hline 13 & 4.01 & .669 & 3.04 & .887 & 11.9 & .000 & .396 & 30 & 2.08 & .908 & 2.17 & .989 & -.92 & .354 & .430 \\
\hline 14 & 4.08 & .744 & 2.88 & 1.020 & 12.9 & .000 & .477 & 31 & 3.56 & .946 & 2.35 & .896 & 12.6 & .000 & .496 \\
\hline 15 & 2.69 & .830 & 1.61 & .756 & 13.05 & .000 & .396 & 32 & 3.38 & .844 & 3.33 & .904 & .53 & .594 & .485 \\
\hline 16 & 3.50 & .960 & 2.32 & .854 & 12.4 & .000 & .419 & 33 & 4.47 & .625 & 3.43 & 1.04 & 11.6 & .000 & .250 \\
\hline 17 & 4.48 & .562 & 3.89 & .724 & 8.7 & .000 & .312 & & & & & & & & \\
\hline
\end{tabular}

Boldface entries indicate values responsible for rejection/deletion

Sample of the research consisted of 298 female (43.4\%), and 389 male $(56.6 \%)$ teachers. Out of these 687 teachers, largest share is of Assistant Professors $(543 ; 79 \%)$ followed by Professors $(77 ; 11.2 \%)$ and Associate Professors (67; $9.8 \%$ ). Teachers from all the age groups and departments were included in the sample and their details are given in Table 1.

\section{Development Process of Attitude Scale towards Online Teaching and Learning}

This scale is based on five point Likert scale and its development and standardization was completed in five stages. In the first stage, different attitude scale and perception of teachers towards online education and use of technology during instruction were studied in order to frame the statements. In the second stage, an item pool of 37 items was prepared in the light of review of literature and earlier available related scales. After that, pilot study of the draft was completed on thirty teachers. Their opinions regarding the understanding and clarity of statements were recorded and included for the improvement of the draft. All these statements were based on five point Likert scale. The respondents can rate their responses on the basis of agreement of disagreement by choosing best appropriate responses (Likert 1932). The responses could be given as "strongly disagree", "disagree", "neutral", "agree", and "strongly agree".

At the third stage, the draft was sent to five experts from the field of educational technology and educational psychology for vetting. The experts examined the relevance of the statements as per the content, clarity and consistency. After receiving the feedback from the experts, the draft was further enhanced and four items were deleted along with modification to eleven other items. Thirty three statements were retained in the item pool which included 22 positive statements and 11 negative statements.

At the fourth stage, the draft containing 33 statements was administered on 687 college and University teachers. The responses from the participants were collected through Google Form and response sheet was created. In the last stage of scale development, the data was analysed by using SPSS 23 version. The normality of the distribution was determined by Gaussian fitting curve using Origin Pro 8.0 software (Fig. 1). A very good fitting of

Table 3 Cronbach's alpha and Split half correlation coefficient for the Scale $($ Items $=30)$

\begin{tabular}{llll}
\hline Cronbach's Alpha & Part 1 & Value & .828 \\
& & N of Items & $15^{\mathrm{a}}$ \\
& Part 2 & Value & .787 \\
& & N of Items & $15^{\mathrm{b}}$ \\
& Total N of Items & 30 \\
Correlation Between Forms & & .694 \\
Spearman-Brown Coefficient & Equal Length & .819 \\
& Unequal Length & .819 \\
Guttman Split-Half Coefficient & & .815 \\
\hline
\end{tabular}

a. The items are: $1,2,3,4,5,6,7,8,9,10,11,12,13,14,15$

b. The items are: $16,17,18,19,20,21,22,23,24,25,26,28,29,31,33$ 
Table 4 Eigen values, variances and total variances of four factors

\begin{tabular}{llll}
\hline Factors & Eigen value & $\begin{array}{l}\text { Percentage of } \\
\text { Variance }\end{array}$ & $\begin{array}{l}\text { Percentage of } \\
\text { Total Variance }\end{array}$ \\
\hline Factor 1 & 7.259 & 24.198 & 24.198 \\
Factor 2 & 2.456 & 8.186 & 32.383 \\
Factor 3 & 2.255 & 7.517 & 39.900 \\
Factor 4 & 1.584 & 5.279 & 45.179 \\
\hline
\end{tabular}

the collected data with Gaussian function has been observed with Chi-square $(\chi 2)$ and adjusted R-square value equal to 8.61 and 0.85 respectively. Perusal of Fig. 1 and obtained fitting parameters ensure that present sample data is normally distributed.

Item analysis was carried out using t-value and r-value. Any item falling short in any of these two criteria was deleted. The t-value was calculated between the items of upper $27 \%$ and lower $27 \%$ of cases. Three items $(27,30,32)$ showed poor discrimination on the basis of their t-value (shown in Table 2), hence were deleted.

The internal consistency of the scale was determined by calculating the value of Cronbach's alpha (0.88), which suggested that the scale possess good reliability (Cronbach 1951). Further, the value of split-half correlation coefficient came out to be 0.82 , which indicate that the scale is reasonably reliable (Table 3 ).

\section{Factor Analysis of the Scale}

Factor analysis (Principal Component Factor) was carried out to examine factor structure of the attitude scale and then followed by varimax rotation. The suitability of data for performing factor analysis was determined by Kaiser-MeyerOlkin (KMO) test and Bartlett's test of Sphericity. The obtained value of KMO test comes out to be 0.897 and it is within acceptability limits as KMO test value greater than 0.60 is acceptable. Hence, the sample size is adequate. Bartlett's test of Sphericity (Approx. Chi square: 6251.627, $p=.000$ ) was significant which also support the validity of factor analysis and data is suitable for reduction. Factor analysis was performed on 30 items after deleting item no. 27, 30 and 32. Five factors which have eigen value higher than 1 . Then parallel analysis was conducted in to order to decide exact number of factors for factor analysis and factor loading greater than 0.4 has been extracted. The eigen values for all the factors are $7.25,2.45,2.25$, and 1.58 . Factor 1 described $24.29 \%$ of total variance, factor 2 described $8.18 \%$ of total variance, factor 3 described $7.51 \%$ of total variance, factor 4 described $5.27 \%$ of total variance. All these factors altogether, described $45.17 \%$ of the variance (Table 4 ) and these factors were given names as per the common characteristics of loaded items on the same factor. Scree plot (Fig. 2) also shows that the curve starts flattening after four factors; as a result, all the four factors for the scale can be retained. Then rotation was done for all the four factors and the results of extracted factor are listed in Table 5 .

Table 5 shows that the factor loading of all the items ranges from 0.432 to 0.789 . The value of the factors between 0.30 and 0.60 indicate medium quality, values between 0.6 and 1 indicate high quality of factors loadings (Kline, 1994). This means that all the 30 items are qualified for the scale. Out of total four factors, factors one includes 10 items $(5,8,17,21,22,23,24,26,28$ and 29). These items measures appreciation and acceptance about online teaching and learning, therefore, this factor was named as "Appreciation for online teaching and learning." Factor 2 includes seven items $(6,12,14,15,18,19$, and 20) which are related with the response of a teacher towards online mode of teaching, this factor is named as "Responsiveness towards online education." Factor 3 includes seven items: 3, 4, 7, 9, 10, 16 and 22 which basically represents the ease of teachers in managing online education, hence, this factor is named as "Proficiency in handling online teaching" Factor 4 includes five items: 1, 2, 5, 11 and 13, which are related with knowledge of teacher about the use of various tools for online teaching,

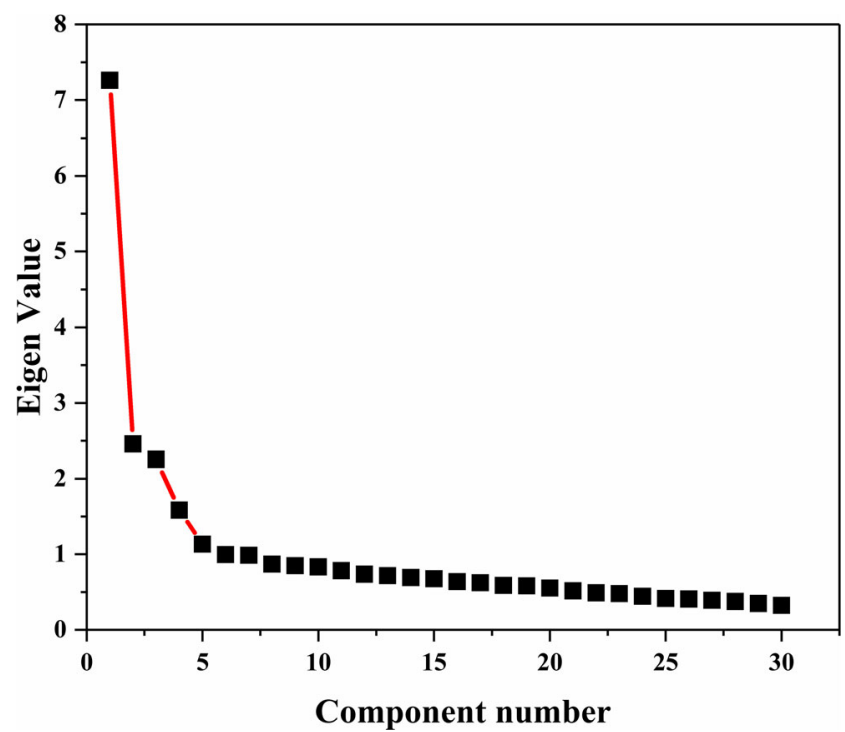

Fig. 2 Scree plot for Attitude scale for teachers towards online teaching and learning 
Table 5 Factor loadings of 30 items

\begin{tabular}{|c|c|c|c|c|c|}
\hline \multirow[t]{2}{*}{ Sr. No. } & \multirow{2}{*}{ Statement } & \multicolumn{4}{|c|}{ Component } \\
\hline & & 1 & 2 & 3 & 4 \\
\hline 25 & Digital Competence is an important twenty-first century skill for every teacher. & .767 & & & \\
\hline 26 & $\begin{array}{l}\text { Online education system provides great opportunity to a teacher for creating and } \\
\text { sharing his/her presentations, video, handouts and weblinks. }\end{array}$ & .717 & & & \\
\hline 17 & Every Teacher should be digitally updated in order to stay relevant. & .632 & & & \\
\hline 21 & I believe that digitally literate teachers have better future. & .619 & & & \\
\hline 33 & I appreciate the use of online teaching in present time. & .611 & & & \\
\hline 24 & One can work collaboratively through online platforms. & .581 & & & \\
\hline 8 & Online teaching has offered new ventures of creativity and opportunities for a teacher. & .502 & & & \\
\hline 29 & Online teaching is very economical. & .486 & & & \\
\hline 23 & Students can learn at their own pace via online learning. & .473 & & & \\
\hline 28 & $\begin{array}{l}\text { I take interest in attending workshops/ training programme related with online } \\
\text { teaching and MOOCs. }\end{array}$ & .444 & & & \\
\hline 12 & Online teaching is more interesting than classroom teaching. & & .703 & & \\
\hline 18 & Students participate more actively during online teaching. & & 698 & & \\
\hline 19 & Student progress can be tracked more efficiently during online teaching & & 673 & & \\
\hline 20 & Online teaching can never replace conventional mode of teaching. & & .585 & & \\
\hline 14 & Online teaching provides more flexibility to the students. & & .518 & & \\
\hline 6 & Online teaching is very good platform for teachers and students & & .514 & & \\
\hline 15 & I feel more comfortable in classroom teaching than online teaching & & .481 & .452 & \\
\hline 4 & I don't feel comfortable while preparing video lectures. & & & .700 & \\
\hline 7 & I find it difficult to teach through online mode. & & & .675 & \\
\hline 10 & I feel stressed about the use of different Learning Management System (LMS) for teaching. & & & .626 & \\
\hline 3 & Online teaching is more challenging. & & & .591 & \\
\hline 22 & Availability of many online teaching tools creates confusion about their usage. & & & .539 & \\
\hline 9 & Online learning is difficult for students. & & .426 & .520 & \\
\hline 31 & I believe that digitally literate teachers have better future. & & & .487 & \\
\hline 16 & Online teaching is time consuming. & & & .423 & \\
\hline 2 & I have sufficient knowledge about different internet tools required for conducting online classes. & & & & .789 \\
\hline 11 & I have clear idea about the use of various tools required for preparing e-content. & & & & .658 \\
\hline 1 & I keep myself updated with new technological innovations in the field of teaching. & & & & .644 \\
\hline 5 & I have good command over Google Suite. & & & & .635 \\
\hline 13 & I know about different Open Educational Resources (OERs). & & & & .576 \\
\hline
\end{tabular}

therefore, this factor is named as "Knowledge of technological reforms." The detail of each factor is summarized in Table 6.
As seen in Table 6, it was determined that the coefficient of correlation between each factor and total score was found to be significant (ranging from .642 to .80). The internal
Table 6 Factor names, Cronbach value, number of the items and coefficient of correlation between different factors and total score of scale

\begin{tabular}{lllll}
\hline Sr. No. & Factor name & $\begin{array}{l}\text { Number } \\
\text { of Items }\end{array}$ & $\begin{array}{l}\text { Correlation } \\
\text { Coefficient }\end{array}$ & $\begin{array}{l}\text { Cronbach } \\
\text { Alpha } \\
\text { Value }\end{array}$ \\
\hline 1 & Appreciation for online teaching and learning & 10 & $.802^{* *}$ & .771 \\
2 & Responsiveness towards online education & 7 & $.776^{* *}$ & .785 \\
3 & Proficiency in handling online teaching & 8 & $.798^{* *}$ & .780 \\
4 & Knowledge of technological reforms & 5 & $.642^{* *}$ & .748 \\
\hline
\end{tabular}

**. Correlation is significant at the 0.01 level (2-tailed) 
Table 7 Percentile norms for the scale

\begin{tabular}{llll}
\hline Percentiles & Attitude Scale Scores & Quantitative interpretation & Qualitative interpretation (Attitude) \\
\hline 90 th & 118 & 118 and above & Highly Favourable \\
75 th & 111 & $111-117$ & Favourable \\
50 th & 103 & $95-110$ & Neutral \\
25 th & 94 & $88-94$ & Unfavourable \\
10 th & 87 & 87 and below & Highly Unfavourable \\
\hline
\end{tabular}

consistency for each factor was also determined (Cronbach coefficient value ranging from .748 to .771) which is satisfactory. Hence, it can be said that this tool is reliable and valid. The data has followed normal/Guassian distribution, therefore, percentile norms for the tool have been determined (Punia and Berwal 2017, 2018) and same has been reported in Table 7. The minimum score of the scale was 30 , while the maximum score was 150 . The scores of the scale were categorized into five categories: highly favourable, favourable, neutral, unfavourable and highly unfavourable attitude.

\section{Description of the Final Attitude Scale}

The final standardized version of the scale contains 30 items which are sorted in to five factors. The scale consisted of both positive (20) and negative statements (10) which are placed randomly in the scale in order to obtain most honest responses. All the items were framed on five point Likert scale. In case of positive statements, strongly agree, agree, neutral, disagree and strongly disagree were scored as 5, 4, 3, 2, 1 respectively, while reverse coding was done for negative statements.

\section{Conclusions}

The present study describes the development and standardization of attitude scale towards online teaching and learning for teachers. This research work was completed on a sample of 687 college and University teachers. This tool is prepared as part of study which is completed during lockdown period due to recent Covid-19 crisis, with the aim to understand the preparedness of higher education teachers in India. Review of literature suggested that most of the existing tools have designed in context to developed countries which have less relevance for developing countries. Therefore, to overcome these limitations, researchers decided to design this new tool to understand the viewpoint of teacher towards online teaching and learning.

The factor analysis process identified five factors for the tool with factor loading greater than 0.4 . These factors were related with teacher's outlook, standpoint, complacency, proficiency and knowledge of technological reforms. Total 30 items were includes in the final scale out of which 20 were positive statements while 10 were negative statements. The scale was checked for its face and construct validity by taking the opinion of experts during its construction process. This scale has good internal consistency $(0.88)$ and reliability $(0.82)$. Like any other tool it has certain limitations that need to be considered before its use outside India. This tool does not contain cultural specific content and can be used across the world after determining its reliability and validity. This limitation of the tool lies in the fact that it was standardized for Indian population, therefore it is suggested that in case of its use outside India, reliability and validity of the tool should be determined in context-specific conditions. Another limitation of the tool is that the collected data is based on teacher self-reported responses, which may be biased. The data for tool construction was collected during COVID-19 pandemic by using google forms, hence authors could not apprehend the interest and willingness of participants during the survey. However, the psychometric analysis of the scale has indicated that this tool is reliable and valid, and can prove valuable in assessing the attitude of teachers towards online education.

Acknowledgements We thank reviewers and teachers/ participants who have made valuable contributions to this study.

Authors' Contributions Anupma Sangwan conceived and designed the study, collected the data, and drafted the manuscript.

Anurag Sangwan conceived and designed the study, collected the data, and critically revised the paper.

Poonam Punia conceived and designed the study, performed the data analysis, and critically revised the paper.

All authors read and approved the final manuscript.

Data Availability The raw data is stored in the form of spread sheet as names and other details of the teachers participated in survey have to be kept confidential. Other material and data analysed using different softwares viz. OriginPro 8.6, Excel, and SPSS may be provided on request.

\section{Compliance with Ethical Standards}

Conflict of Interests The authors declare that they have no conflict of interest. 
Ethical Approval This article does not report on any studies with animals performed by any of the authors. However, ethical approval from the participants has been taken at the time of filling of questioner as google form.

Informed Consent Informed consent has been obtained at the time of filling of questioner as google form.

\section{References}

Adebowale, O. F., Adewale, I. A., \& Oyeniram, F. M. (2010). Computer interest, approval and confidence of secondary school students in three elected local government of Lagos state: Implications for global computerization. International Journal of Education and Development using Information \& Communication Technology, 6(1), 40-52.

Akaslan, D., \& Law, E. L. (2011). Measuring teachers' readiness for elearning in higher education institutions associated with the subject of electricity in Turkey. In 2011 IEEE Global Engineering Education Conference (EDUCON) (pp. 481-490). IEEE.

Al Gamdi, M. A., \& Samarji, A. (2016). Perceived barriers towards elearning by faculty members at a recently established university in Saudi Arabia. International Journal of Information and Education Technology, 6(1), 23.

Alanazy, S. M. (2017). Factors affecting faculty attitude for adopting online learning at Aljouf University, Saudi Arabia. Journal of Education and Learning, 7(1), 154.

Anderson, B., \& Tracey, K. (2001). Digital living: The impact (or otherwise) of the internet on everyday life. American Behavioral Scientist, 45(3), 456-475.

Buabeng-Andoh, C. (2012). Factors influencing teachers' adoption and integration of information and communication technology into teaching: A review of the literature. International Journal of Education and Development using Information and Communication Technology, 8(1), 136-155.

Chien, S.-P., Wu, H.-K., \& Hsu, Y.-S. (2014). An investigation of teachers' beliefs and their use of technology-based assessments. Computers in Human Behaviour, 31, 198-210.

Costley, K. C. (2014). The positive effects of technology on teaching and student learning. Arkansas Tech University.

Cronbach, L. J. (1951). Coefficient alpha and the internal structure of tests. Psychometrika, 16(3), 297-334.

Draude, B., \& Brace, S. (1999). Assessing the impact of technology on teaching and learning: Student perspectives.

Duart, J. M. (2011). The net on teaching processes at the university introduction. Comunicar, 37, 10-13. https://doi.org/10.3916/C372011-02.

Eagly, A., \& Chaiken, S. (2007). The advantages of an inclusive definition of attitude. Social Cognition, 25(5), 582-602.

Enayati, T., Modanloo, Y., \& Kazemi, F. S. M. (2012). Teachers' attitudes towards the use of technology in education. Journal of Basic and Applied Scientific Research, 2(11), 010958-010963.

Fazio, R. H. (2007). Attitudes as object-evaluation associations of varying strength. Social Cognition, 25(5), 603-637.

Gardner, D. G., Dukes, R. L., \& Discenza, R. (1993). Computer use, selfconfidence and attitudes: A causal analysis. Computers in Human Behavior, 9(3), 427-440.

Garrison, D. R. (Ed.). (2011). E-learning in the 21st century. London: Routledge Taylor \& Francis Group.

Ghavifekr, S., \& Rosdy, W. A. W. (2015). Teaching and learning with technology: Effectiveness of ICT integration in schools. International Journal of Research in Education and Science, 1(2), $175-191$.
Girgurovic, M. (2010). Technology-enhanced blended language learning in an ESL class: a description of a model and application of the diffusion of innovation theory. Unpublished $\mathrm{PhD}$ Thesis, Iowa State University

Graff, M. (2003). Cognitive style and attitudes towards online learning and assessment methods. Electronic Journal of e-Learning Methods, 1(1), 21-28.

Haythornthwaite, C., \& Wellman, B. (2002). The internet in everyday life: An introduction. The Internet in everyday life, 3-41.

Hürsen, C.. (2012). Determine the attitudes of teachers towards professional development activities. Procedia Technology, 1, 420-425.

IvyPanda. (2019, June 10). Teachers' attitudes towards the use of technology in teaching and learning. Retrieved from https://ivypanda. com/essays/teachers-attitudes-towards-the-use-of-technology-inteaching-and-learning/.

Jones, T., \& Clarke, V. A. (1994). A computer attitude scale for secondary students. Computers Education, 22(4), 315-318.

Jovanova-Mitkovska, S. (2010). The need of continuous professional teacher development. Procedia-Social and Behavioral Sciences, 2(2), 2921-2926.

Kalanda, K. (2005). Factors influencing college students' attitude towards technology. Unpublished master's dissertation, University of South Africa. Retrieved from https://core.ac.uk/download/pdf/43165004. pdf.

Kay, R. H. (1993). An exploration of theoretical and practical foundations for assessing attitudes toward computers: The computer attitude measure (CAM). Computers in Human Behavior, 9, 371-386.

Kisanga, D., \& Ireson, G. (2016). Test of e-learning related attitudes (TeLRA) scale: Development, reliability and validity study. International Journal of Education and Development using ICT, 12(1), 20-36.

Kraut, R., Mukhopadhyay, T., Szczypula, J., Kiesler, S., \& Scherlis, B. (1999). Information and communication: Alternative uses of the internet in households. Information Systems Research, 10(4), 287303.

Krishnakumar, R., \& Rajesh, K. M. (2011). Attitude of teachers' of higher education towards E-learning. Journal of Education and Practice, 2(4), 48-53.

Lateef, A. R., \& Alaba, S. O. (2013). Influence of gender and attitude of pre-service teachers towards on-line instruction in a selected university in South-Western Nigeria. Asian Social Science, 9(4), 84.

Lazar, S. (2015). The importance of educational technology in teaching. International Journal of Cognitive Research in Science, Engineering and Education, 3(1), 111-114.

Lea, L., Clayton, M., Draude, B., \& Barlow, S. (2001). The impact of technology on teaching and learning. Educause Quarterly, 24(2), 69-69.

Likert, R. (1932). "A technique for the measurement of attitudes". Archives of psychology, no.140. New York: New York University.

Mahajan, G. (2016). Attitude of teachers towards the use of Technology in Teaching. Educational Quest-An International Journal of Education and Applied Social Sciences, 7(2), 141-146.

Martin, F., Budhrani, K., \& Wang, C. (2019). Examining faculty perception of their readiness to teach online. Online Learning, 23(3), $97-$ 119.

Meelissen, R. M., \& Drent, M. (2008). Gender difference in computer attitudes: Does the school matter? Computers in Human Behaviour, 24(3), 969-985. https://doi.org/10.1016/j.chb.2007.03.001.

Mercader, C., \& Gairín, J. (2020). University teachers' perception of barriers to the use of digital technologies: The importance of the academic discipline. International Journal of Educational Technology in Higher Education, 17(1), 1-14.

Metin, M., Yilmaz, G. K., Coskun, K., \& Birisci, S. (2012). Developing an attitude scale towards using instructional Technologies for preService Teachers. Turkish Online Journal of Educational Technology-TOJET, 11(1), 36-45. 
Nair, I., \& Das, V. M. (2012). Using technology acceptance model to assess teachers' attitude towards use of technology as teaching tool: A SEM approach. International Journal of Computer Applications, 42(2), 1-6.

Panda, S., \& Mishra, S. (2007). E-learning in a mega Open University: Faculty attitude, barriers and motivators. Educational Media International, 44(4), 323-338.

Papp, R. (1998). Student perception \& knowledge about information technology: A computer attitude and experience survey to measure changes. Journal of Education for Management Information Systems, 5(1), 54-62.

Punia, P., \& Berwal, S. (2017). Development and standardization of an alienation scale for visually impaired students. Journal of Visual Impairment \& Blindness, 111(5), 427-439.

Punia, P., \& Berwal, S. (2018). Development and standardization of mental health battery for visually impaired. International Journal of Special Education, 33(2), 382-396.

Rogers, E. M. (2003). Diffusion of innovations (5th ed.). New York: Simon \& Schuster, Inc..

Salmon, G. (2011). E-moderating: the key to teaching and learning online (3rd ed.). New York, NY: Routledge.

Schwarz, N. (2007). Attitude construction: Evaluation in context. Social Cognition, 25(5), 638-656.

Suri, G., \& Sharma, S. (2016). Investigation of Teacher's attitude towards e-learning-a case study of Panjab University, Chandigarh, India. Gian Jyoti E-Journal, 6(3), 1-10.

Teo, T. (2009). Modelling technology acceptance in education: A study of pre-service teachers. Computers and Education, 52, 302-312.

Teo, T. (2010). Development and validation of the E-learning acceptance measure (ElAM). The Internet and Higher Education, 13(3), 148152
UNESCO. (2009). Trends in Global Higher Education: Tracking an Academic Revolution. Paris: A Report Prepared for the UNESCO 2009 World Conference on Higher Education.

Uzunboylu, H. (2007). Teacher attitudes toward online education following an online inservice program. International Journal on E-learning, 6(2), 267-277.

Van den Berg, H., Manstead, A. S. R., van der Pligt, J., \& Wigboldus, D. H. J. (2006). The impact of affective and cognitive focus on attitude formation. Journal of Experimental Social Psychology, 42, 373379.

Van Raaij, E. M., \& Schepers, J. J. L. (2008). The acceptance and use of a virtual learning environment in China. Computers and Education, 50(3), 838-852.

Wang, M., MacArthur, D. A., \& Crosby, B. (2003). A descriptive study of community college teachers' attitudes toward online learning. TechTrends, 47(5), 28-31.

Wasserman, E., \& Migdal, R. (2019). Professional development: Teachers' attitudes in online and traditional training course. Online Learning, 23(1), 132-143. https://doi.org/10.24059/olj.v23i1.1299.

Weller, M. (2007). Virtual learning environments: Using, choosing and developing your VLE. London: Routledge Taylor and Francis Group.

Wells, P., de Lange, P., \& Fieger, P. (2008). Integrating a virtual learning environment into a second-year accounting course: Determinants of overall student perception. Accounting \& Finance, 48(3), 503-518.

Publisher's Note Springer Nature remains neutral with regard to jurisdictional claims in published maps and institutional affiliations. 